\title{
Gallium-Containing Hydroxyapatite as a Promising Material for Photocatalytic Performance
}

\author{
Rafael Lisandro Pereira Rocha ${ }^{1,2}$, Thalena Lima Silva ${ }^{1}$, Francisca Pereira Araujo ${ }^{1}$, Ewerton Gomes Vieira ${ }^{3}$,

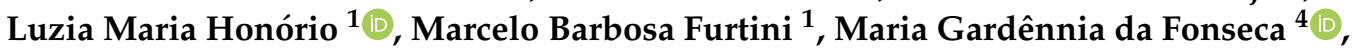 \\ Edson Cavalcanti da Silva-Filho ${ }^{1} \mathbb{D}$ and Josy Anteveli Osajima ${ }^{1, *} \mathbb{C}$
}

1 Interdisciplinary Laboratory for Advanced Materials (LIMAV), UFPI, Teresina 64049-550, Brazil; rafael@ifpi.edu.br (R.L.P.R.); thalena12@hotmail.com (T.L.S.); araujop15@gmail.com (F.P.A.); luzia_quimica@yahoo.com.br (L.M.H.); marcelofurtini@ufpi.edu.br (M.B.F.); edsonfilho@ufpi.edu.br (E.C.d.S.-F.)

2 Federal Institute of Piaui, IFPI, Campus Central, Teresina 64000-040, Brazil

3 Federal Institute of Maranhão, IFMA, Campus Buriticupu, Buriticupu 65393-000, Brazil; ewertonvieira@ufpi.edu.br

4 Núcleo de Pesquisa e Extensão-Laboratório de Combustíveis e Materiais (NPE-LACOM), Universidade Federal da Paraíba, João Pessoa 58051-970, Brazil; mgardennia@quimica.ufpb.br

* Correspondence: josyosajima@ufpi.edu.br

check for updates

Citation: Pereira Rocha, R.L.; Silva, T.L.; Araujo, F.P.; Vieira, E.G.; Honório, L.M.; Furtini, M.B.; da Fonseca, M.G.; Silva-Filho, E.C.d.; Osajima, J.A. Gallium-Containing Hydroxyapatite as a Promising Material for Photocatalytic Performance. Minerals 2021, 11, 1347. https://doi.org/10.3390/min11121347

Academic Editor: Keiko Sasaki

Received: 20 October 2021

Accepted: 27 November 2021

Published: 30 November 2021

Publisher's Note: MDPI stays neutral with regard to jurisdictional claims in published maps and institutional affiliations.

Copyright: (c) 2021 by the authors. Licensee MDPI, Basel, Switzerland. This article is an open access article distributed under the terms and conditions of the Creative Commons Attribution (CC BY) license (https:/ / creativecommons.org/licenses/by/ $4.0 /)$.

\begin{abstract}
The development of photocatalystsor their modification to obtain new photocatalytic performances for the removal of contaminants is a challenge. Hydroxyapatite (HAp), $\left(\mathrm{Ca}_{10}\left(\mathrm{PO}_{4}\right)_{6}(\mathrm{OH})_{2}\right)$, is an inorganic component with a high superficial area and low toxicity and the presence of metal in its structure can be an interesting strategy for the photocatalytic approach. This work aimed to synthesize gallium-containing HAp (Ga-HAp) as a promising material for photocatalytic performance. The synthesis was performed by the suspension-precipitation method. The material was characterized by X-ray diffraction (XRD) and X-ray photoelectron spectroscopy (XPS). Morphological analysis employed field emission scanning electron microscope (FESEM) and the elemental analysis by energy-dispersive spectroscopy (EDS). To evaluate the photocatalytic activity, methylene blue (MB) dye was used as a pollutant model under UV light for $120 \mathrm{~min}$. The influence of Ga-HAp concentration $\left(0.25,0.50\right.$, and $\left.1.00 \mathrm{~g} \cdot \mathrm{L}^{-1}\right)$ and kinetic reaction was also studied. The Ga-HAp was successfully obtained by the suspension-precipitation method. The structural characterization by XRD and FESEM-EDS elucidated the presence of gallium in the structure of hydroxyapatite. The XPS results indicated the substitution of gallium in the crystal lattice of the material. The discoloration rate of MB dye using Ga-Hap was calculated by pseudo first-order kinetics, and the best rate constant was $7.5 \times 10^{-3} \mathrm{~min}^{-1}$ using $1.00 \mathrm{~g} \cdot \mathrm{L}^{-1}$ of photocatalyst. The concentration of Ga-HAp influenced the photocatalytic process, because the discoloration rate increased as a function of the concentration of material. Therefore, Ga-HAp is a promising material for environmental remediation.
\end{abstract}

Keywords: hydroxyapatite; methylene blue; dye; discoloration; metal

\section{Introduction}

The provision of clean water is a challenging proposition around the world. Over the years, intense human activity has been directly related to environmental problems. For example, the industrial sector is responsible for releasing different organic pollutants that are not easily removed by nature. In the case of the textile industry, an estimated 200,000 tons of synthetic dyes are released into the environment [1]. In addition to the risks to various types of ecosystems, toxic wastewater from the textile industry is also related to several types of health problems in humans [2].

Some methods suggested as strategies for removing organic pollutants from wastewater include physical-chemical, biological, and chemical. Each of these methods has 
advantages and disadvantages [3]; however, complete mineralization of the pollutant requires a potentially efficient strategy that is both low-cost and easy to handle. Advanced oxidation processes (AOPs) can satisfactorily remove recalcitrant pollutants, including synthetic dyes. The efficiency of this method is related to the formation of highly reactive free radicals, such as the hydroxyl radical, which are capable of promoting the oxidation of the organic molecule until total mineralization [4]. Photocatalytic oxidation is an example of AOPs based on activation of a semiconductor by UV or visible radiation and has been extensively investigated for the removal of different pollutants [5].

During photocatalysis, semiconductors, such as $\mathrm{TiO}_{2}, \mathrm{ZnO}, \mathrm{Al}_{2} \mathrm{O}_{3}$, and CdS, absorb light and form electron/hole $\left(\mathrm{e}^{-} / \mathrm{h}^{+}\right)$charge carriers that promote the generation of oxygenated radical species [6,7]. However, some materials, including the classic $\mathrm{TiO}_{2}$ photocatalyst, have disadvantages, such as low surface area and low selectivity, in the adsorption of dye molecules, resulting in reduced photocatalytic efficiency [8,9]. Therefore, some strategies have been developed to improve the photocatalytic activity of these semiconductors. For example, the presence of metals or nonmetals and formation of heterojunctions can favor the formation of defect states and minimize the recombination effect of the $\mathrm{e}^{-} / \mathrm{h}^{+}$pair [10]. Furthermore, the photocatalytic support materials can enhance photocatalytic performance, due to the surface area [11,12]. However, obtaining these materials requires the use of toxic reagents or the performance of additional heat treatments, implying high energy demand.

Photocatalysis reactions occur at the solid-liquid interface of the photocatalyst. Therefore, the material must have a high surface area to ensure that the pollutant molecules are adsorbed and degraded. Hydroxyapatite $(\mathrm{HAp}),\left(\mathrm{Ca}_{10}\left(\mathrm{PO}_{4}\right)_{6}(\mathrm{OH})_{2}\right)$, is an inorganic component of bone matrix found in the vertebrate skeletal [13]. This bioceramic is inexpensive and has been used in applications that require biocompatibility, low toxicity, and osteo conductivity, including biomedical application [14]. As it is considered an element of the biological skeleton, HAp has been used in environmental remediation due to its biocompatibility, stability, and high specific surface area, which exhibits potential for immobilization on stable metal-HAp, ensuring the concept of green photocatalysts in photocatalytic reactions [15-17]. In addition, different forms and derived compounds in pure, doped, supported, and hetero structured form are cited in the literature as improvements in degradation processes [18-22].

HAp does not have photocatalytic activity, but metal can be an alternative for photocatalysis systems [23].However, due to the high surface area of this ceramic, it has been used to assist in environmental remediation processes [8,24]. The substitution of the calcium ion $\left(\mathrm{Ca}^{2+}\right)$ in the HAp structure by other mono or divalent cations directly influence the physicochemical and biological properties of this phosphate [25,26]. Modified hydroxyapatite (HAp) photocatalysts have gradually emerged in photocatalysis as a series of promising compounds, providing new opportunities in the field of pollutant remediation [27-30]. Al-Ahmed et al. (2020) observed that HAp doped with palladium ions demonstrated effective dye removal capacity [24]. Similarly, Basfer et al. (2021) found that the doping of HAp with vanadate ions favored the photocatalytic activity of the obtained material [26].

Currently, the doping of photocatalysts with metals represents an efficient strategy to improve the performance of these materials in the removal of recalcitrant pollutants. However, some metals can exhibit toxicity and represent additional risks to the environment, such as silver ions [31]. Gallium ions exhibit toxicity significantly less, and have already been reported as doping ions of the HAp structure [32]. Tohelp obtain new materials for removing pollutants, this work aimed to synthesize and characterize gallium-containing HAp for photo discoloration of methylene blue dye as a model pollutant under UV light. The synthesis was performed by the suspension-precipitation method. The material was characterized by X-ray diffraction (XRD), emission scanning electron microscope (FESEM) and the elemental analysis by energy-dispersive spectroscopy (EDS), diffuse reflectance, and X-ray photoelectron spectroscopy (XPS). The techniques showed the crystallity of material, the morphology and the substitution of the metal in its structure, and to correlate 
that these characteristics are important for the photocatalytic process. The discoloration rate of MB dye using Ga-HAp was calculated by pseudo first-order kinetics, and the best rate constant using $1.00 \mathrm{~g} \cdot \mathrm{L}^{-1}$ of photocatalyst. The concentration of Ga-HAp influenced the photocatalytic process, because the discoloration rate increased as a function of the concentration of material.

\section{Materials and Methods}

\subsection{Reagents}

To synthesize HAp particles doped with gallium $(5 \% \mathrm{~m} / \mathrm{m})$, named Ga-HAp, the reagents-calcium hydroxide (Vetec, Tai Po, Hong Kong, $\mathrm{Ca}(\mathrm{OH})_{2}$ ), dibasic ammonium phosphate (Neon, New York City, NY, USA, $\left(\mathrm{NH}_{4}\right)_{2} \mathrm{HPO}_{4}$ ), and gallium nitrate (SigmaAldrich, St. Louis, $\left.\mathrm{MO}, \mathrm{USA}, \mathrm{Ga}\left(\mathrm{NO}_{3}\right)_{3}\right)$-were used without previous purification processes. The deionized water used for the synthesis processes was obtained by purification in a Milli-Q ${ }^{\circledR}$ system (Millipore Corporation, Burlington, MA, USA).

\subsection{Synthesis of Ga-Containing Hydroxyapatite}

Ga-HAp was synthesized using the suspension-precipitation method (SPM) [33], with $\mathrm{Ca}(\mathrm{OH})_{2},\left(\mathrm{NH}_{4}\right)_{2} \mathrm{HPO}_{4}$, and $\mathrm{Ga}\left(\mathrm{NO}_{3}\right)_{3}$ as the precursor reagents. The amounts were stoichiometrically determined according to a molar ratio of $\mathrm{Ca} / \mathrm{P} \sim 1.67$. The addition of the gallium dopant $(x \mathrm{mols} \mathrm{Ga}=5.00 \% \mathrm{~mol}$ or $0.050 \mathrm{~mol}$ ) occurred in a proportion to the percentage of calcium hydroxyapatite $\left(\mathrm{Ca}_{10-\mathrm{x}} \mathrm{Ga}_{x}\left(\mathrm{PO}_{4}\right)_{6}(\mathrm{OH})_{2}\right)$ (Equation (1)):

$$
\begin{gathered}
\mathrm{Ca}(\mathrm{OH})_{2(\mathrm{~s})}+0.05 \mathrm{Ga}\left(\mathrm{NO}_{3}\right)_{3(\mathrm{aq})}+6\left(\mathrm{NH}_{4}\right)_{2} \mathrm{HPO}_{4(\mathrm{~s})} \rightarrow \\
\mathrm{Ca}{ }_{9.95} \mathrm{Ga}_{0.05}\left(\mathrm{PO}_{4}\right)_{6}(\mathrm{OH})_{2 \downarrow}+18 \mathrm{H}_{2} \mathrm{O}_{(\mathrm{l})}+12 \mathrm{NH}_{3(\mathrm{~g})}
\end{gathered}
$$

The $\mathrm{Ca}(\mathrm{OH})_{2},\left(\mathrm{NH}_{4}\right)_{2} \mathrm{HPO}_{4}$, and $\mathrm{Ga}\left(\mathrm{NO}_{3}\right)_{3}$ were dissolved in $100 \mathrm{~mL}$ of deionized water. The synthesis was carried out at room temperature under stirring for approximately $3 \mathrm{~h}$ at basic $\mathrm{pH}=11$ (the synthesis occurred with no need for $\mathrm{pH}$ adjustment). The resulting colloidal dispersions were centrifuged and washed with deionized water, and the product was dried in the oven at $110{ }^{\circ} \mathrm{C}$ for about $12 \mathrm{~h}$. The obtained powders were milled with the aid of the mortar and pestle and passed in a 35 VT sieve with an aperture of $425 \mu \mathrm{m}$ ) [33].

\subsection{Characterization}

The synthesized powders were characterized by X-ray diffraction (XRD). The diffractograms were collected from $5^{\circ}$ to $75^{\circ}$ at $2 \theta$ with a scan rate of $2^{\circ} / \mathrm{min}$ and a data collection time of $40 \mathrm{~min}$. Monochromatic $\mathrm{Cu}-\mathrm{K} \alpha$ radiation $(\lambda=1.5406 \AA)$ was used on an LABX-XRD 600 by Shimadzu (Kyoto, Japan). Phase composition identification was performed by the Rietveld method using GSAS EXPGUI 2012 software (2.0 version, Los Alamos, NM, USA). The crystallinity degree $\left(\mathrm{CD}_{\text {raio- }}\right)$ was calculated according to Person et al. [34]. Height was measured between the value at the top of a peak and the value of the minimum that separates it from the peak. Precise values of the upper and minimum intensities were obtained after the deconvolution of the spectra using standard routines and Voigt-type profiles employing the PeakFit program. These values divided by the net intensity of the highest peak obtained the value of the $C D_{\text {raio- } X}$ as shown in Equation (2):

$$
\mathrm{CD}_{\text {raio-X }}=(\mathrm{H}(202)+\mathrm{H}(300)+\mathrm{H}(112)) / \mathrm{H}(211)
$$

where $H(202), H(300), H(112)$, and $H(211)$ are the heights of the peaks corresponding to there flections (202), (300), (112), and (211), respectively.

For the Rietveld refinement analysis [35], XRD data were collected in the $2 \theta$ range from $10^{\circ}$ to $110^{\circ}$ with a scanning rate of $0.02^{\circ} / \mathrm{min}$ and exposure time of $90 \mathrm{~min}$. Calibration of the X-ray diffractometer was performed prior to XRD pattern acquisition. The NIST standard reference material $\mathrm{LaB}_{6}$ (NIST-600b) was used in this calibration. The collected XRD pattern of the reference material was then used to obtain the initial input parameters for all the refinements. In addition, the crystallographic information on the Inorganic 
Crystal Structure Database (ICSD) (reference code: 1-072-1243) for hydroxyapatite [36], was employed as the initial structural refinement model. X-ray photoelectron spectroscopy (XPS) was used to identify chemical species on the surface of the materials. The XPS were obtained using a spectrometer system (ESCA+, Scienta-Omicron, Taunusstein, Germany) equipped with a hemispherical analyzer (EA125) and a monochromatic Al K $\alpha$ X-ray

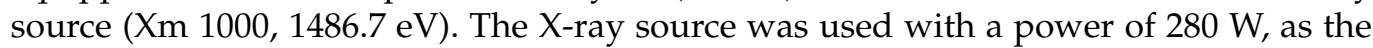
spectrometer worked in a constant pass energy mode of $50 \mathrm{eV}$. The morphological analyses of the synthesized materials were investigated using a field emission scanning electron microscope (FESEM) (QUANTA 250 FEI, FEI Company, Eindhoven, The Netherlands). Elemental analysis by energy-dispersive spectroscopy (EDS) was performed using an Apollo X EDAX (FEI Company, Eindhoven, The Netherlands) probe attached to an FESEM. The bandgap energy was deduced from to transmittance spectra using the Kubelka-Munk method through the Tauc relationship, as shown in Equation (3):

$$
\alpha h v \propto\left(h v-E_{g}\right)^{n}
$$

where $\alpha$ is the absorption coefficient, $h$ is Planck's constant, $v$ corresponds to the frequency of radiation, $E_{g}$ is the band gap energy, and $n$ can assume a value of $\frac{1}{2}$ or 2 , for the cases of direct and for indirect transitions, respectively [37]. For HAp, the transition is assumed to be indirectly [38].

\subsection{Photocatalytic Experiments}

The photocatalytic process tests were conducted using methylene blue dye(MB) solution $\left(1.5 \times 10^{-5} \mathrm{~mol} \cdot \mathrm{L}^{-1}\right)$ as the pollutant model under magnetic stirring at $700 \mathrm{rpm}$ in a borosilicate reactor under UV radiation (125 W Hg without bulb). The lamp was $15 \mathrm{~cm}$ of the reactor.The potency of the lamp was monitored by a radiometer (HANNA-HI 97550-Luxmeter). The reaction temperature was controlled at $25.0 \pm 1.0^{\circ} \mathrm{C}$. As a typical experiment, a certain amount of photocatalyst $\left(0.25,0.50\right.$, and $\left.1.00 \mathrm{~g} \cdot \mathrm{L}^{-1}\right)$ was added into $100.0 \mathrm{~mL}$ of the dye solution. The kinetic parameter is shown in Table S1. Before each run, the suspensions were stirred in the dark at $600 \mathrm{rpm}$ until reaching the adsorption equilibrium (40 min). The dark experiment as displayed in Figure S1. During the experiment, aliquots were collected at different times until $120 \mathrm{~min}$. After irradiation, the samples were centrifuged at $5000 \mathrm{rpm}$ for $5 \mathrm{~min}$. The band at $664 \mathrm{~nm}$ was monitored using a spectrophotometer (Agilent Technologies, Cary 60 UV-Vis) in the range between 200 and $800 \mathrm{~nm}$, and thepercentage of discoloration of the MB was estimated using Equation (4):

$$
\text { Discoloration }(\%)=\left[\left(C_{0}-C\right) / C_{0}\right] \times 100
$$

where $\mathrm{C}_{0}$ and $\mathrm{C}$ correspond to the initial $\mathrm{MB}$ concentration and the final dye concentration $(\mathrm{t}=120 \mathrm{~min})$, respectively.

The discoloration of MB in the presence of Ga-HAp was fitted based on Equation (5):

$$
\ln \left(\mathrm{C} / \mathrm{C}_{0}\right)=-\mathrm{kt}
$$

where $\mathrm{C}_{0}$ and $\mathrm{C}$ correspond to the initial $\mathrm{MB}$ concentration and the dye concentration in time $t$, respectively; $k$ is apparent rate constant $\left(\mathrm{min}^{-1}\right)$; and $t$ is the reaction time ( $\mathrm{min}$ ).

The reuse experiment was carried out using the concentration of $1.00 \mathrm{~g} \cdot \mathrm{L}^{-1}$ of material in MB dye solution $\left(1.5 \times 10^{-5} \mathrm{~mol} \cdot \mathrm{L}^{-1}\right)$. Photocatalysis followed the same procedure described above. At the end of the photocatalytic process, the material was washed three times with deionized water and dried for $24 \mathrm{~h}$ in an oven. After this time, the material was weighed again and following the same photocatalytic procedure to determine the percentage of discoloration of the MB was estimated using Equation (4). 


\section{Results and Discussion \\ 3.1. Structural Characterization}

Ga-HAp were characterized by X-ray diffraction and analyzed by the Rietveld method (Figure 1). From the results of the diffractogram (Figure 1a), the material obtained presented good crystallinity, the apatite phase was confirmed, and other crystalline phases were not observed in the composition of Ga-HAp. The average crystallite size was $\sim 41.50 \mathrm{~nm}$, which was calculated by Equation (2). The specific crystallographic planes that characterize the crystalline phase of hydroxy apatite were identified as (111), (002), (102), (210), (211), (202), (310), (312), (213), and (511). The planes identified in the XRD indicate successful formation of the hydroxyapatite phase. These planes are in accordance with the information available in the ICSD catalog 1-072-1243 (hexagonal space group P63/m and Laue group 6/m), which is in accordance the standard ISO BS 13779-3:2008 [39].
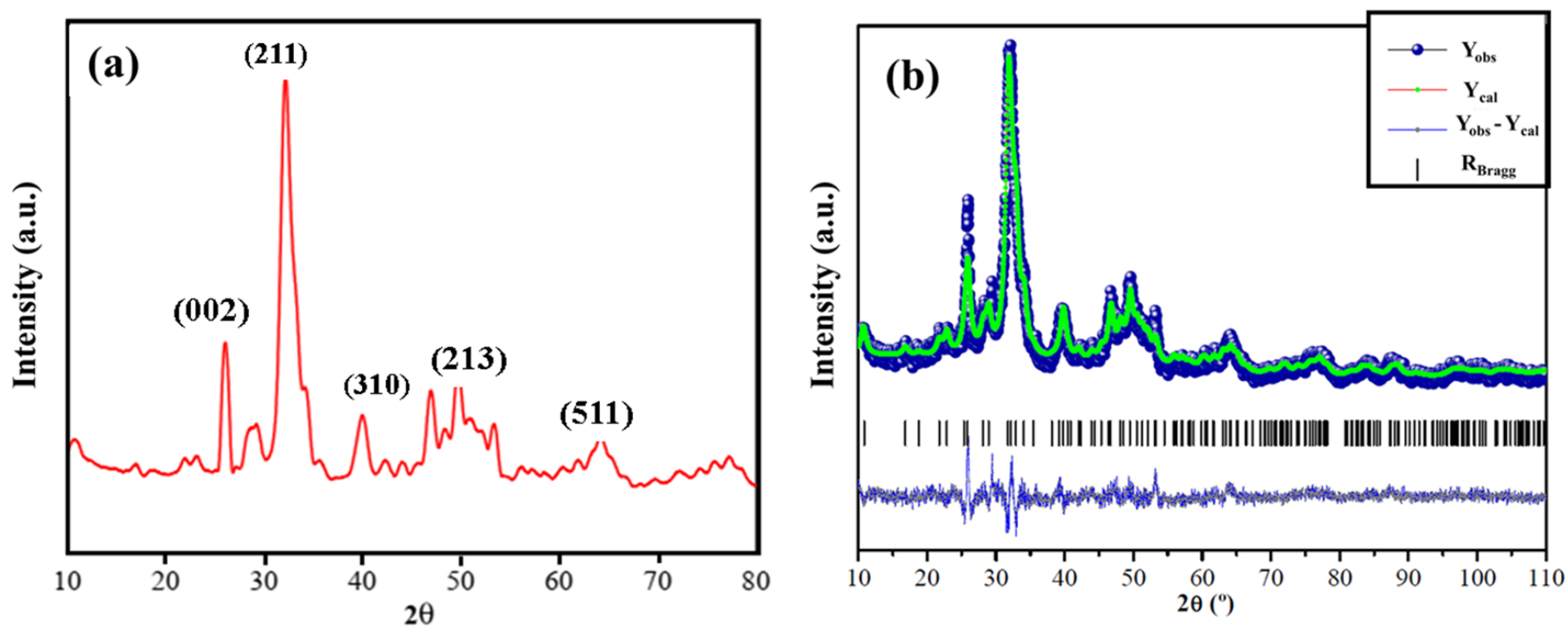

Figure 1. (a) XRD pattern for the (a) Ga-HAp powders synthesized by the suspension-precipitation method (SPM) and Rietveld refinement profiles (b) from XRD data for Ga-HAp.

Figure $2 \mathrm{~b}$ shows the precise fit between the experimental diffractogram (Yobs) and the diffraction pattern calculated by the Rietveld refinement (Ycal) after the Rietveld refinement. The value of $\chi^{2}$ (convergence factor or $\mathrm{Chi}^{2}$ ) was 1.966. The parameter qualified the refinement was satisfactory because the results obtained with the refinement were acceptable. The Rwp must have values close to $10 \%$ for tetragonal, orthorhombic, rhombohedral, or hexagonal structures [40]. The Rwp value for the Ga-HAp was $11.00 \%$. The cell parameters of Ga-HAp a $=\mathrm{b}=9.43 \AA$, and $\mathrm{c}=6.89 \AA$, and unit cell volume of $531.39 \AA^{3}$. The unit cell parameter values for ICSD $\mathrm{N}_{0} \cdot 01-072-1243$ card are: $\mathrm{a}=\mathrm{b}=9.42 \AA$ and $\mathrm{c}=6.88 \AA$ and $\mathrm{V}=529.09 \AA^{3}$ and the unit cell parameters calculated by Oliveira et al. [41] are: $\mathrm{a}=\mathrm{b}=9.43 \AA$ and $\mathrm{c}=6.88 \AA$ and $\mathrm{V}=528.85 \AA^{3}$.

According to previous work [32], it is expected that the incorporation of $\mathrm{Ga}^{3+}$ in the Hap structure causes a significant change in the lattice parameters, since the ionic radius size of the cations occupying the same coordination site in the hydroxyapatite structure is different. For example, $\mathrm{Ga}^{3+} \mathrm{e} \mathrm{Ca}^{2+}$ with a coordination number $(\mathrm{CN})$ of 6 have an ionic radius of $\mathrm{rGa}^{3+}=0.62 \AA$ and $\mathrm{rCa}^{2+}=1.00 \AA$, respectively; while $\mathrm{Ga}^{3+}$ and $\mathrm{P}^{5+}$ with $\mathrm{CN}=4$ have an ionic radius of $\mathrm{rGa}^{3+}=0.47 \AA$ and $\mathrm{rP}^{5+}=0.17 \AA$, respectively. In our work, a small increase in the values of some lattice parameters was observed after incorporation of $\mathrm{Ga}^{3+}$ in the hydroxyapatite structure. For example, adiscrete variation due to the low concentration of gallium ions did not affect the parameters with an approximate decrease in the volume ( $528.55 \AA^{3}$ to $531.39 \AA^{3}$ ) of the Ga-HAp unit cell when compared to the volume unit cell of the ICSD card. Some works [42-44] reported the synthesis of HA containing 
gallium and most of them suggest that doping occurs by replacing $\mathrm{Ca}^{2+}$ ions by $\mathrm{Ga}^{3+}$. However, these authors fail to affirm the $\mathrm{Ga}^{3+}$ replacement site in the network due to the absence of appropriate experimental characterization.
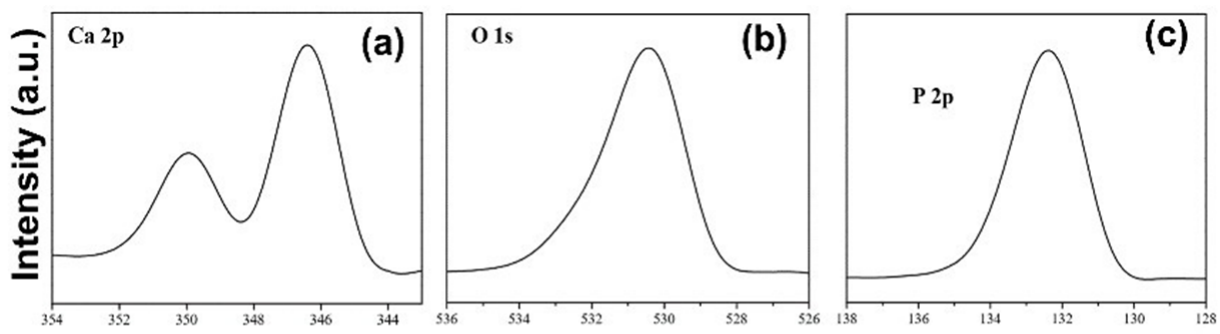

Binding energy (eV)

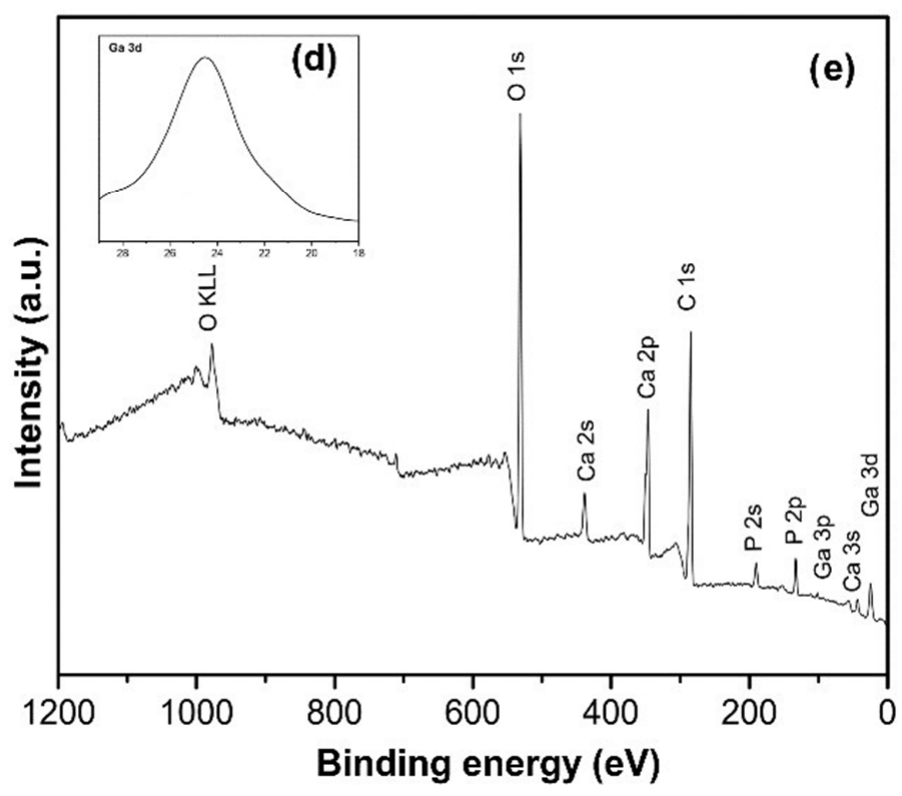

Figure 2. XPS spectra of Ga-HAp showing the devolution of biding energies of (a) calcium, (b) oxygen, (c) phosphorous, (d) gallium, and (e) XPS spectrum of Ga-HAp.

The small variation suggests that subtle changes in the crystal at tice occurred through doping with $\mathrm{Ga}$, confirming the XRD results. These parameters are very close when compared with the literature [32]. The introduction of Ga into hydroxy apatite may be located not only in the nanocrystalline core, but also in the hydrated surface layer of the material, especially in the amorphous hydrated surface layer of hydroxyapatite. This behavior may have occurred in the Ga-HAp as this material did not exhibit high crystallinity as shown in the XRD results.

Figure 2 presents the XPS spectra of Ga-HAp. The spectra indicated the presence of calcium (Ca 2p) (Figure 2a), oxygen (O 1s) (Figure 2b), phosphorus (P2p) (Figure 2c), and gallium (Ga 3d) (Figure 2d) peaks. The main characteristic peaks of the chemical elements that constitute the Ga-HAp $\left(\mathrm{Ca}_{9.95} \mathrm{Ga}_{0.05}\left(\mathrm{PO}_{4}\right)_{6}(\mathrm{OH})_{2}\right)$ were identified: $531.79 \mathrm{eV}(\mathrm{O} 1 \mathrm{~s})$, $436.41 \mathrm{eV}$ (Ca 2s), $345.83 \mathrm{eV}$ (Ca 2p), $190.23 \mathrm{eV}$ (P 2s), $132.68 \mathrm{eV}$ (P 2p), $43.69 \mathrm{eV}$ (Ca 3s), and $23.98 \mathrm{eV}$ (Ga 3d).

The Ca 2p XPS spectrum (Figure 2a) contains the doublet band, which is characteristic of $\mathrm{Ca}-\mathrm{O}$ compounds. The $\mathrm{Ca} 2 \mathrm{p}$ XPS line at $345.83 \mathrm{eV}$ binding energy is attributed to the following $\mathrm{Ca}-\mathrm{O}$ bindings in hydroxyapatite: $\mathrm{Ca}-\mathrm{O}, \mathrm{Ca}-\mathrm{OH}$, and $\mathrm{Ca}-\mathrm{Ca}$. The $\mathrm{O} 1$ s spectra can be observed from the intense peak that has binding energy around $531 \mathrm{eV}$ corresponding to the hydroxyl $(\mathrm{OH})$ ions, the $\mathrm{P}-\mathrm{O}$ [26] bond, and the anionic oxygen of the phosphate $\left(\mathrm{PO}_{4}{ }^{3-}\right)$ [45]. It is believed in the partial substitution of the phosphate group by 
gallium and the identification of the P-O bond associated with the O1s nucleus present in the crystal structure of Ga-HAp, favoring the incorporation.

The $\mathrm{P} 2 \mathrm{p}$ line positioned at $132.68 \mathrm{eV}$ (Figure 2c) indicates the bonding of phosphor to oxygen in the $\left(\mathrm{PO}_{4}\right)^{3-}$ group in the Ga-HAp structure [46], and the Ga $3 \mathrm{~d}$ peak positioned at $23.98 \mathrm{eV}$ (Figure 2d) and it can be attributed to the formation of the set $\mathrm{O} 2 \mathrm{~s}(\mathrm{II})+\mathrm{Ga} 3 \mathrm{~d}$, which produces the connection of the type Ga-O [47]. In the case of the B.E value, Ga could be substituting Ca in its unit cell parameters of Ga-HAp for the Ga 3d peak. Basfer et al. [26] report in the P 2p spectrum a peak at $133.65 \mathrm{eV}$ involving V-HAP. Furthermore, it shows the importance of analyzing the high-resolution spectra of Se and confirms the encapsulation of vanadium ions in the structural system.

FESEM/EDS was used for the morphological investigation and qualitative composition of Ga-HAp. Figure 3 presents the EDS micrograph sand spectra. Elementary constituents of hydroxyapatite $(\mathrm{Ca}, \mathrm{P}$, and $\mathrm{O})$ and $\mathrm{Ga}$ do pant were identified by EDS (Figure 3a). This result corroborates with the XPS analysis. FESEM micrographs (Figure 3b) showed that astrongtendency to form particles that organize in agglomerate. These particles did not have uniform morphology and present an irregular surface. It was also possible to infer that the surface of the material tends to have an organization with an increase in the size of the agglomerates.

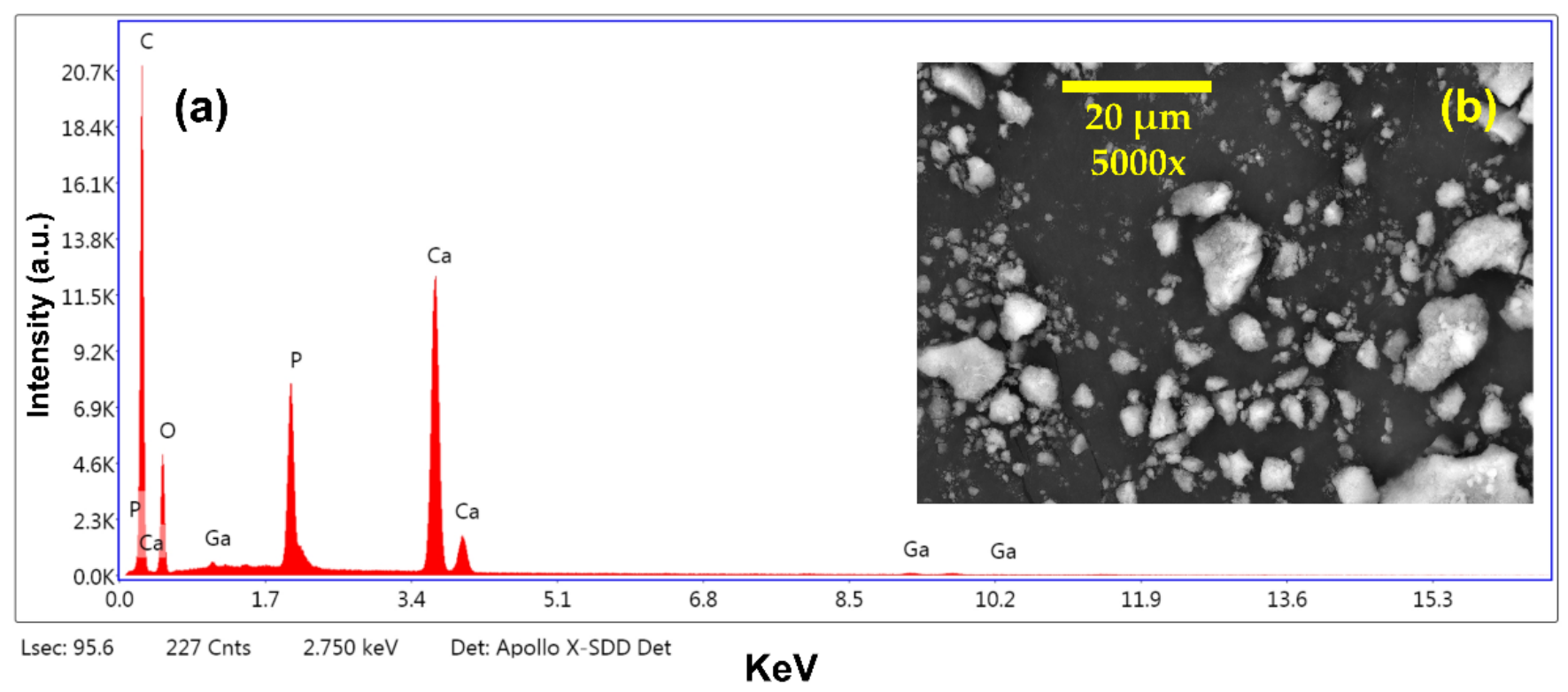

Figure 3. (a) EDS analysis of Ga-HA and (b) FESEM micrographs of Ga-HAp.

The bandgap energy was obtained from to the diffuse reflection data (Figure 4). The estimated bandgap energy value using extrapolated linear portion of the curves was $5.35 \mathrm{eV}$. The energy band gap for pure hydroxyapatite was previously reported and the range was $4.9-5.6 \mathrm{eV}[38,48]$.

\subsection{Photocatalytic Investigation}

The electronic absorption spectra of the MB dye in the presence of Ga-HAp under UV light as a function of irradiation time are shown in Figure $5 \mathrm{a}-\mathrm{c}$. The gradual decrease in the concentration of the irradiated pollutant in the presence of catalyst for all concentrations investigated suggests that the obtained materials are photoactive, because HAp does not exhibit appreciable photocatalytic activity [23]. 


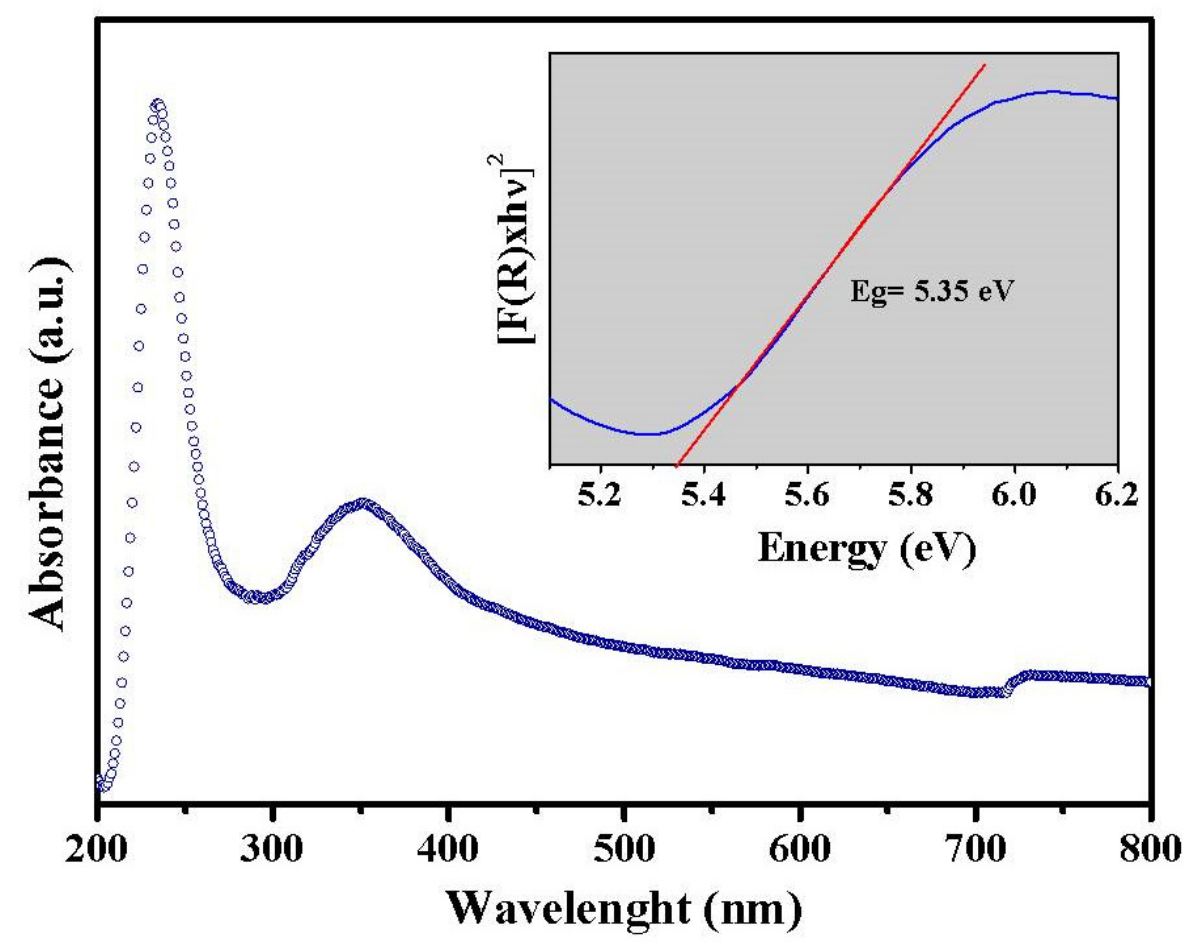

Figure 4. UV-Vis absorbance and DRS spectra of Ga-HAp.

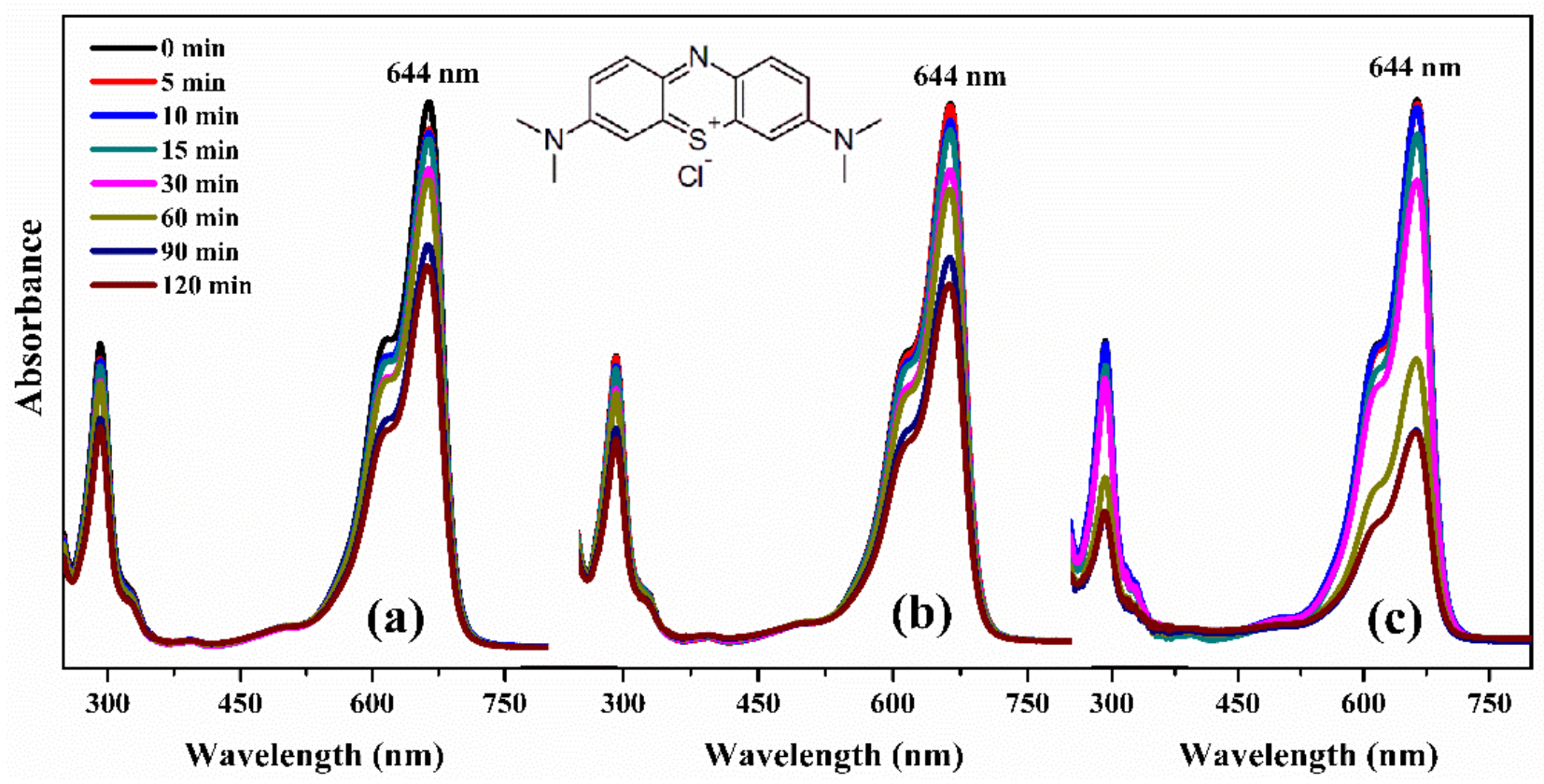

Figure 5. Absorption spectra of the irradiated MB solution using Ga-HAp photocatalyst in different concentrations: (a) 0.25 , (b) 0.50 , and (c) $1.00 \mathrm{~g} \cdot \mathrm{L}^{-1}$ under UV light in different concentrations.

The dependence of $M B$ dye discoloration using Ga-HAp as a function of the $C / C_{0}$ ratio was studied, considering the main dye band at $664 \mathrm{~nm}$ (Figure 6a). The photolysis not suffered changed in the photocatalytic process. The increase in the concentration of the photocatalyst resulted in a decrease of the $C / C_{0}$ ratio due to photodiscoloration of the $M B$ dye mediated by the presence of Ga-HAp. 

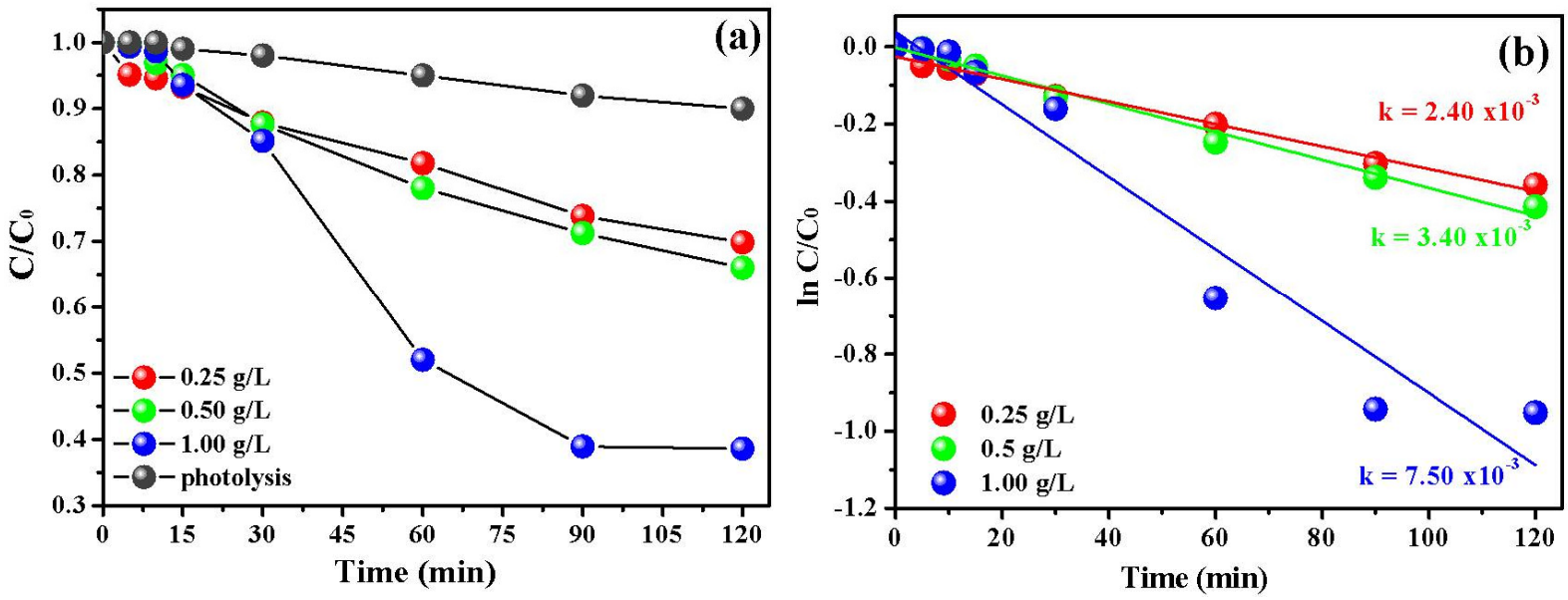

Figure 6. (a) Variation of MB absorption at different concentrations of photocatalyst and (b) pseudo first-order kinetic withthe apparent rate constant.

A brief kinetic study of the MB dye photodiscoloration using Ga-HAp was also investigated in this work, and these results are shown in Figure 6b. The degradation reaction of non-degradable azo-dyescan is described by a first-order kinetic mechanism, as suggested in the literature $[49,50]$. The dark experiment (Figure S1) showed that it did not have adsorption, because it isnot included in Figure $6 \mathrm{a}, \mathrm{b}$. The linear fit between $\ln \left(\mathrm{C} / \mathrm{C}_{0}\right)$ as a function of the irradiation time was observed in all photocatalytic systems. This behavior is typical of a pseudo-first-order kinetic. The rate constants for discoloration of MB dye using Ga-HAp were $2.40 \times 10^{-3}, 3.40 \times 10^{-3}$, and $7.50 \times 10^{-3} \mathrm{~min}^{-1}$ when the concentration of photocatalyst used was $0.25,0.50$, and $1.00 \mathrm{~g} \cdot \mathrm{L}^{-1}$, respectively. This behavior implied that the rate constant increased as a function of the concentration of the photocatalyst.

The percentage of discoloration for each system was determined based on Equation (4), and the results are provided in Figure 7. The MB discoloration was 30.12, 42.0, and 62.0\% for $0.25,0.50$, and $1.00 \mathrm{~g} \cdot \mathrm{L}^{-1}$ of photocatalyst concentration, respectively. The Ga-Hap showed a percentage of discoloration almost 3.0 times lower in the third cycle, suggesting a good stability (Figure S2). Similar results were previously described by [51], who used the compound $\mathrm{Ag}_{3} \mathrm{PO}_{4}$ combined with HAp to analyze photocatalytic tests and achieved $60 \%$ degradation of the methylene blue dye under UV radiation [52].

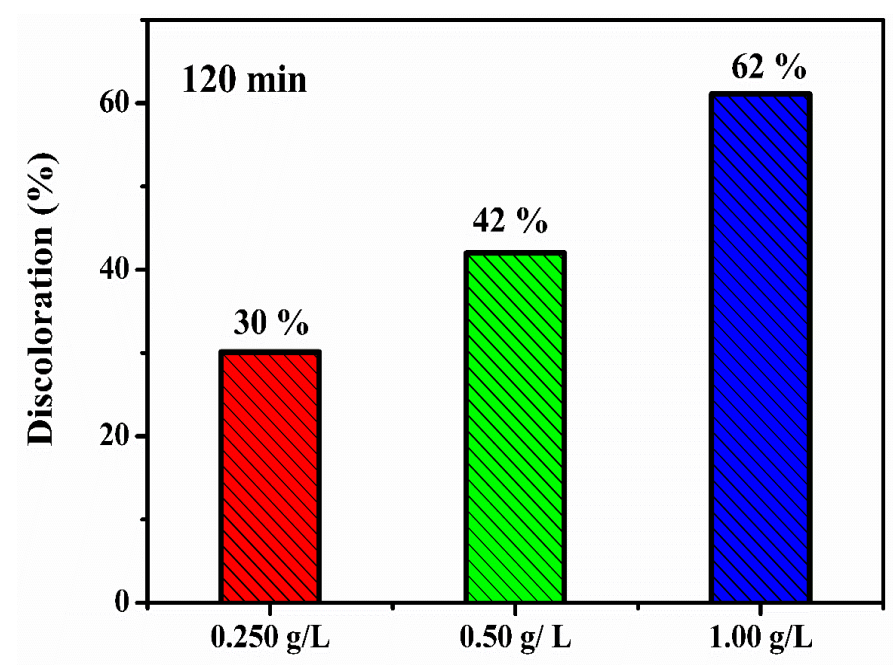

Figure 7. Percentage of MB discoloration from photocatalytic tests under UV light using Ga-HAp in different concentrations. 
Sathiyavimal et al. [53] described the synthesis of HAp from fish bones for environmental application (FB-HAp). In this study, the potential of FB-HAp was verified against the degradation of Congo red and crystal violet dyes, exhibiting $77 \%$ and $87 \%$ degradation, respectively. The degradations of dyes occurred based on the reaction from the valence bond to the conducting band that produces electron-hole pairs generated under radiation. Recently, Al-Ahmed et al. (2020) reported that Pd-HAp in different concentrations of the doping ion reached $\mathrm{MB}$ dye degradation in the range between 26 and $86.4 \%$ after 120 min of irradiation [23]. Amdlous et al. (2021) observed an MB degradation rate above $70.0 \%$ using the hydroxyapatite/platinum catalyst, although only for large amounts of the photocatalyst [50]. Furthermore, another study reported an efficiency of $75.0 \%$ of HAp nanostructures to degrade $\mathrm{MB}$ after $4 \mathrm{~h}$ under continuous irradiation [54].

The effect ofthe Ga-HA pconcentration on MB discoloration can be explained by the fact that increasing the catalyst amount leads to the generation of more active sites on the catalyst surface and more hydroxyl radicals, leading to an increase of the degradation efficiency [55,56]. According to Reddy et al. [57], the use of hydroxyapatite as a photocatalyst under UV irradiation can be explained considering that the catalytic phenomenon in HAp is due to photoinduced electronic excitation attributed to oxygen vacancies that contributes to the formation of radicals capable of oxidizing pollutant molecules and reacting with water and other ions, which through successive reactions form ${ }^{\bullet} \mathrm{OH}$ and degrade the pollutant.

\section{Conclusions}

Ga-HAp was successfully obtained by the suspension-precipitation method. The X-ray diffraction showed that the material has good crystallinity. The micrographs evidenced that the material had a strong tendency to form particles that organize in agglomerate. The X-ray photoelectron spectroscopy results indicated the substitution of gallium in the crystal lattice of the material. The discoloration rate of MB dye using Ga-Hap was calculated by pseudo first-order kinetic, and the best rate constant was $7.5 \times 10^{-3} \mathrm{~min}^{-1}$ using $1.00 \mathrm{~g} \cdot \mathrm{L}^{-1}$ of the photocatalyst. The concentration of Ga-HAp influenced the photocatalytic process, because the discoloration rate increased as function of the concentration of material. Therefore, Ga-HAp is a promising material for the photocatalytic performance of pollutants.

Supplementary Materials: The following are available online at https:/ /www.mdpi.com/article/ 10.3390/min11121347/s1, Figure S1: Adsorption dark test: (a) spectral variation of MB in different times, Table S1: Kinetic parameters used for MB dye dislocation using Ga-Hap under UV light, Figure S2: Reuse of Ga-Hap $\left(1 \mathrm{~g} \cdot \mathrm{L}^{-1}\right)$ using MB dye $\left(1.5 \times 10^{-5} \mathrm{~mol} \cdot \mathrm{L}^{-1}\right)$ under UV light.

Author Contributions: Conceptualization, R.L.P.R. and T.L.S.; methodology, R.L.P.R. and T.L.S.; validation, F.P.A. and E.G.V.; formal analysis, L.M.H., F.P.A. and E.G.V.; investigation R.L.P.R. and T.L.S.; writing—original draft preparation, L.M.H., F.P.A. and M.B.F.; writing—review and editing, M.G.d.F; visualization, M.G.d.F.; supervision, E.C.d.S.-F. and J.A.O.; project administration, J.A.O.; funding acquisition, M.B.F. and E.C.d.S.-F. All authors have read and agreed to the published version of the manuscript.

Funding: This research was funded by CAPES, CNPq and FAPEPI for all the financial support and study/research grants.

Acknowledgments: The authors would like to thank their institutions Federal University of Piauí, Federal University of Paraíba and Federal Institute of Piauí.

Conflicts of Interest: The authors declare no conflict of interest.

\section{References}

1. Al-Mamun, M.R.; Kader, S.; Islam, M.S.; Khan, M.Z.H. Photocatalytic activity improvement and application of UV-TiO 2 photocatalysis in textile wastewater treatment: A review. J. Environ. Chem. Eng. 2019, 7, 103248. [CrossRef]

2. Ge, M.; Hu, Z.; Wei, J.; He, Q.; He, Z. Recent advances in persulfate-assisted $\mathrm{TiO}_{2}$-based photocatalysis for wastewater treatment: Performances, mechanism and perspectives. J. Alloys Compd. 2021, 888, 161625. [CrossRef] 
3. Malato, S.; Blanco, J.; Vidal, A.; Richter, C. Photocatalysis with solar energy at a pilot-plant scale: An overview. Appl. Catal. B Environ. 2002, 37, 1-15. [CrossRef]

4. Wang, J.L.; Xu, L.J. Advanced oxidation processes for wastewater treatment: Formation of hydroxyl radical and application. Crit. Rev. Environ. Sci. Technol. 2012, 42, 251-325. [CrossRef]

5. Araujo, F.P.; Trigueiro, P.; Honório, L.M.C.; Oliveira, D.M.; Almeida, L.C.; Garcia, R.P.; Lobo, A.O.; Cantanhêde, W.; Silva-Filho, E.C.; Osajima, J.A. Eco-friendly synthesis and photocatalytic application of flowers-like ZnO structures using Arabic and Karaya Gums. Int. J. Biol. Macromol. 2020, 165, 2813-2822. [CrossRef] [PubMed]

6. Qian, R.; Zong, H.; Schneider, J.; Zhou, G.; Zhao, T.; Li, Y.; Yang, J.; Bahnemann, D.W.; Pan, J.H. Charge carrier trapping, recombination and transfer during $\mathrm{TiO}_{2}$ photocatalysis: An overview. Catal. Today 2018, 335, 78-90. [CrossRef]

7. Araujo, F.P.; Trigueiro, P.; Honório, L.M.C.; Furtini, M.B.; Oliveirab, D.M.; Almeidac, L.C.; Peña-Garcia, R.R.; Viana, B.C.; SilvaFilho, E.C.; Osajima, J.A. Novel green approach based on $\mathrm{ZnO}$ nanoparticles and polysaccharides for photocatalytic performance. Dalt. Trans. 2020, 49, 16394-16403. [CrossRef]

8. Mohseni-Salehi, M.S.; Taheri-Nassaj, E.; Hosseini-Zori, M. Effect of dopant (Co, Ni) concentration and hydroxyapatite compositing on photocatalytic activity of titania towards dye degradation. J. Photochem. Photobiol. A Chem. 2018, 356, 57-70. [CrossRef]

9. De Oliveira, W.V.; Morais, A.I.S.; Honorio, L.M.C.; Almeida, L.C.; Viana, B.C.; Furtini, M.B.; Silva-filho, E.C.; Osajima, J.A. TiO 2 Immobilized on Fibrous Clay as Strategies to Photocatalytic Activity. Mater. Res. 2020, 23, 1-10. [CrossRef]

10. Matos, J.; Ocares-Riquelme, J.; Poon, P.S.; Montaña, R.; García, X.; Campos, K.; Hernández-Garrido, J.C.; Titirici, M.M. C-doped anatase $\mathrm{TiO}_{2}$ : Adsorption kinetics and photocatalytic degradation of methylene blue and phenol, and correlations with DFT estimations. J. Colloid Interface Sci. 2019, 547, 14-29. [CrossRef] [PubMed]

11. Honorio, L.M.C.; Trigueiro, P.A.; Viana, B.C.; Ribeiro, A.B.; Osajima, J.A. Nanostructured Materials for the Photocatalytic Degradation of Organic Pollutants in Water; Springer: Cham, Switzerland, 2019. ISBN 9783030337445.

12. da Silva Lopes, J.; Rodrigues, W.V.; Oliveira, V.V.; Braga, A.D.; da Silva, R.T.; França, A.A.; da Paz, E.C.; Osajima, J.A.; da Silva Filho, E.C. Modification of kaolinite from Pará/Brazil region applied in the anionic dye photocatalytic discoloration. Appl. Clay Sci. 2019, 168, 295-303. [CrossRef]

13. da Silva, O.G.; da Silva Filho, E.C.; da Fonseca, M.G.; Arakaki, L.N.H.; Airoldi, C. Hydroxyapatite organofunctionalized with silylating agents to heavy cation removal. J. Colloid Interface Sci. 2006, 302, 485-491. [CrossRef] [PubMed]

14. Szcześ, A.; Hołysz, L.; Chibowski, E. Synthesis of hydroxyapatite for biomedical applications. Adv. Colloid Interface Sci. 2017, 249, 321-330. [CrossRef]

15. Valizadeh, S.; Rasoulifard, M.H.; Dorraji, M.S.S. Modified Fe3O4- hydroxyapatite nanocomposites as heterogeneous catalysts in three UV, Vis and Fenton like degradation systems. Appl. Surf. Sci. 2014, 319, 358-366. [CrossRef]

16. Yao, Z.; Wang, X.; Hu, M.; Yao, Z.; Liu, X.; Ma, L.; He, Z.; Wang, X. Enhancement mechanism of hydroxyapatite for photocatalytic degradation of gaseous formaldehyde over $\mathrm{TiO}_{2}$ /hydroxyapatite. J. Taiwan Inst. Chem. Eng. 2018, 85, 91-97.

17. da Silva, O.G.; da Fonseca, M.G.; Arakaki, L.N.H. Silylated calcium phosphates and their new behavior for copper retention from aqueous solution. Colloids Surf. A Physicochem. Eng. Asp. 2007, 301, 376-381. [CrossRef]

18. Pereira, M.B.B.; Honório, L.M.C.; Lima-Júnior, C.G.; Silva Filho, E.C.; Gaslain, F.; Rigaud, B.; Fonseca, M.G.; Jaber, M. Modulating the structure of organofunctionalized hydroxyapatite/tripolyphosphate/chitosan spheres for dye removal. J. Environ. Chem. Eng. 2020, 8, 103980. [CrossRef]

19. Ekka, B.; Nayak, S.R.; Achary, L.S.K.; Sarita; Kumar, A.; Mawatwal, S.; Dhiman, R.; Dash, P.; Patel, R.K. Synthesis of hydroxyapatite-zirconia nanocomposite through sonochemical route: A potential catalyst for degradation of phenolic compounds. J. Environ. Chem. Eng. 2018, 6, 6504-6515. [CrossRef]

20. Shariffuddin, J.H.; Jones, M.I.; Patterson, D.A. Greener photocatalysts: Hydroxyapatite derived from waste mussel shells for the photocatalytic degradation of a model azo dye wastewater. Chem. Eng. Res. Des. 2013, 91, 1693-1704. [CrossRef]

21. Manoj, M.; Mangalaraj, D.; Meena, P.; Yuan, A. Facile development and structural investigations of HAp and HAp/Ta nanostructures: Photocatalytic activity against Turq blue GL dye. Mater. Res. Express 2019, 7, 015012. [CrossRef]

22. Liu, X.; Ma, J.; Yang, J. Visible-light-driven amorphous Fe(III)-substituted hydroxyapatite photocatalyst: Characterization and photocatalytic activity. Mater. Lett. 2014, 137, 256-259. [CrossRef]

23. Bouyarmane, H.; El Bekkali, C.; Labrag, J.; Es-saidi, I.; Bouhnik, O.; Abdelmoumen, H.; Laghzizil, A.; Nunzi, J.M.; Robert, D. Photocatalytic degradation of emerging antibiotic pollutants in waters by $\mathrm{TiO}_{2} / \mathrm{Hydroxyapatite} \mathrm{nanocomposite} \mathrm{materials.}$ Surfaces and Interfaces 2021, 24, 101155. [CrossRef]

24. Al-Ahmed, Z.A.; Al-Radadi, N.S.; Ahmed, M.K.; Shoueir, K.; El-Kemary, M. Dye removal, antibacterial properties, and morphological behavior of hydroxyapatite doped with Pd ions. Arab. J. Chem. 2020, 13, 8626-8637. [CrossRef]

25. Sousa, R.B.; Dametto, A.C.; Sabio, R.M.; de Carvalho, R.A.; Vieira, E.G.; do Amaral Oliveira, A.F.; Ribeiro, L.K.; Barud, H.S.; Silva-Filho, E.C. Cerium-doped calcium phosphates precipitated on bacterial cellulose platform by mineralization. Ceram. Int 2020, 46, 26985-26990. [CrossRef]

26. Basfer, N.M.; Mansour, S.F.; Ahmed, M.K. Physicochemical properties of hydroxyapatite modified with vanadium ions for degradation of methylene blue. J. Mol. Struct. 2021, 1240, 130562. [CrossRef]

27. Pang, Y.; Kong, L.; Chen, D.; Yuvaraja, G.; Mehmood, S. Facilely synthesized cobalt doped hydroxyapatite as hydroxyl promoted peroxymonosulfate activator for degradation of Rhodamine B. J. Hazard. Mater. 2020, 384, 121447. [CrossRef] [PubMed] 
28. Zou, R.; Xu, T.; Lei, X.; Wu, Q.; Xue, S. Novel and efficient red phosphorus/hollow hydroxyapatite microsphere photocatalyst for fast removal of antibiotic pollutants. J. Phys. Chem. Solids 2020, 139, 109353. [CrossRef]

29. Lei, X.; Xu, T.; Yao, W.; Wu, Q.; Zou, R. Hollow hydroxyapatite microspheres modified by CdS nanoparticles for efficiently photocatalytic degradation of tetracycline. J. Taiwan Inst. Chem. Eng. 2020, 106, 148-158. [CrossRef]

30. Le Hoang, T.T.T.; Insin, N.; Sukpirom, N. Catalytic activity of silver nanoparticles anchored on layered double hydroxides and hydroxyapatite. Inorg. Chem. Commun. 2020, 121, 108199. [CrossRef]

31. Marimuthu, S.; Antonisamy, A.J.; Malayandi, S.; Rajendran, K.; Tsai, P.C.; Pugazhendhi, A.; Ponnusamy, V.K. Silver nanoparticles in dye effluent treatment: A review on synthesis, treatment methods, mechanisms, photocatalytic degradation, toxic effects and mitigation of toxicity. J. Photochem. Photobiol. B Biol. 2020, 205, 111823. [CrossRef]

32. Pajor, K.; Pajchel, Ł.; Zgadzaj, A.; Piotrowska, U.; Kolmas, J. Modifications of Hydroxyapatite by Gallium and Silver IonsPhysicochemical Characterization, Cytotoxicity and Antibacterial Evaluation. Int. J. Mol. Sci. 2020, 21, 5006. [CrossRef]

33. Vieira, E.; Silva, M.; Maia-Filho, A.; Ferreira, D.; Figuerêdo-Silva, J.; Rovaris, K.; Fialho, A.C.; Leite-Oliveira, A.; Menezes de Oliveira, A.L.; da Fonseca, M.G.; et al. Effect of Cerium-Containing Hydroxyapatite in Bone Repair in Female Rats with Osteoporosis Induced by Ovariectomy. Minerals 2021, 11, 377. [CrossRef]

34. Person, A.; Bocherens, H.; Mariotti, A.; Renard, M. Diagenetic evolution and experimental heating of bone phosphate. Palaeogeogr. Palaeoclimatol. Palaeoecol. 1996, 126, 135-149. [CrossRef]

35. Rietveld, H.M. A profile refinement method for nuclear and magnetic structures. J. Appl. Crystallogr. 1969, 2, 65-71. [CrossRef]

36. Kim, T.-R.; Kim, M.-S.; Goh, T.S.; Lee, J.S.; Kim, Y.H.; Yoon, S.-Y.; Lee, C.-S. Evaluation of Structural and Mechanical Properties of Porous Artificial Bone Scaffolds Fabricated via Advanced TBA-Based Freeze-Gel Casting Technique. Appl. Sci. 2019, 9, 1965. [CrossRef]

37. Ercan, I.; Kaygili, O.; Kayed, T.; Bulut, N.; Tombuloğlu, H.; İnce, T.; Al Ahmari, F.; Kebiroglu, H.; Ates, T.; Almofleh, A.; et al. Structural, spectroscopic, dielectric, and magnetic properties of $\mathrm{Fe} / \mathrm{Cu}$ co-doped hydroxyapatites prepared by a wet-chemical method. Phys. B Condens. Matter 2022, 625, 413486. [CrossRef]

38. Bystrov, V.S.; Piccirillo, C.; Tobaldi, D.M.; Castro, P.M.L.; Coutinho, J.; Kopyl, S.; Pullar, R.C. Oxygen vacancies, the optical band gap (Eg) and photocatalysis of hydroxyapatite: Comparing modelling with measured data. Appl. Catal. B Environ. 2016, 196, 100-107. [CrossRef]

39. Posner, A.S.; Perloff, A.; Diorio, A.F. Refinement of the hydroxyapatite structure. Acta Crystallogr. 1958, 11, 308-309. [CrossRef]

40. Vieira, E.G.; Sousa, P.A.A.; Matos, J.M.E.; Santos, M.R.M.C. Síntese pelo método da coprecipitação e caracterização estrutural do tungstato de cálcio com estrutura tipo scheelita. Cerâmica 2013, 59, 417-425. [CrossRef]

41. Oliveira, C.; de Oliveira, A.L.M.; Chantelle, L.; Landers, R.; Medina-Carrasco, S.; Del Mar Orta, M.; Silva Filho, E.C.; Fonseca, M.G. Zinc (II) modified hydroxyapatites for tetracycline removal: Zn (II) doping or ZnO deposition and their influence in the adsorption. Polyhedron 2021, 194. [CrossRef]

42. Ballardini, A.; Montesi, M.; Panseri, S.; Vandini, A.; Balboni, P.G.; Tampieri, A.; Sprio, S. New hydroxyapatite nanophases with enhanced osteogenic and anti-bacterial activity. J. Biomed. Mater. Res. Part A 2018, 106, 521-530. [CrossRef] [PubMed]

43. Kurtjak, M.; Vukomanović, M.; Krajnc, A.; Kramer, L.; Turk, B.; Suvorov, D. Designing Ga(iii)-containing hydroxyapatite with antibacterial activity. RSC Adv. 2016, 6, 112839-112852. [CrossRef]

44. Melnikov, P.; Teixeira, A.R.; Malzac, A.; Coelho, M.d.B. Gallium-containing hydroxyapatite for potential use in orthopedics. Mater Chem. Phys. 2009, 117, 86-90. [CrossRef]

45. Neelgund, G.M.; Oki, A. Photocatalytic activity of hydroxyapatite deposited graphene nanosheets under illumination to sunlight. Mater. Res. Bull. 2022, 146, 111593. [CrossRef]

46. Dreghici, D.B.; Butoi, B.; Predoi, D.; Iconaru, S.L.; Stoican, O.; Groza, A. Chitosan-Hydroxyapatite Composite Layers Generated in Radio Frequency Magnetron Sputtering Discharge: From Plasma to Structural and Morphological Analysis of Layers. Polymers 2020, 12, 3065. [CrossRef] [PubMed]

47. Zatsepin, D.A.; Boukhvalov, D.W.; Zatsepin, A.F.; Kuznetsova, Y.A.; Gogova, D.; Shur, V.Y.; Esin, A.A. Atomic structure, electronic states, and optical properties of epitaxially grown $\beta-\mathrm{Ga}_{2} \mathrm{O}_{3}$ layers. Superlattices Microstruct. 2018, 120, 90-100. [CrossRef]

48. Rajhi, F.Y.; Yahia, I.S.; Zahran, H.Y.; Kilany, M. Synthesis, structural, optical, dielectric properties, gamma radiation attenuation, and antimicrobial activity of V-doped hydroxyapatite nanorods. Mater. Today Commun. 2021, 26, 101981. [CrossRef]

49. Vukomanović, M.; Žunič, V.; Otoničar, M.; Repnik, U.; Turk, B.; Škapin, S.D.; Suvorov, D. Hydroxyapatite/platinum biophotocatalyst: A biomaterial approach to self-cleaning. J. Mater. Chem. 2012, 22, 10571-10580. [CrossRef]

50. Amedlous, A.; Amadine, O.; Essamlali, Y.; Maati, H.; Semlal, N.; Zahouily, M. Copper Loaded Hydroxyapatite Nanoparticles as eco-friendly Fenton-like catalyst to Effectively Remove Organic Dyes. J. Environ. Chem. Eng. 2021, 9, 105501. [CrossRef]

51. Piccirillo, C.; Pinto, R.A.; Tobaldi, D.M.; Pullar, R.C.; Labrincha, J.A.; Pintado, M.M.E.; Castro, P.M.L. Light induced antibacterial activity and photocatalytic properties of Ag/Ag3PO4 -based material of marine origin. J. Photochem. Photobiol. A Chem. 2015, 296, 40-47. [CrossRef]

52. Piccirillo, C.; Dunnill, C.W.; Pullar, R.C.; Tobaldi, D.M.; Labrincha, J.A.; Parkin, I.P.; Pintado, M.M.; Castro, P.M.L. Calcium phosphate-based materials of natural origin showing photocatalytic activity. J. Mater. Chem. A 2013, 1, 6452. [CrossRef]

53. Sathiyavimal, S.; Vasantharaj, S.; Shanmugavel, M.; Manikandan, E.; Nguyen-Tri, P.; Brindhadevi, K.; Pugazhendhi, A. Facile synthesis and characterization of hydroxyapatite from fish bones: Photocatalytic degradation of industrial dyes (crystal violet and Congo red). Prog. Org. Coat. 2020, 148, 105890. [CrossRef] 
54. Reeta Mary, I.; Leethiyal, R.; Sekar, P.; Mangalaraj, D.; Viswanathan, C.; Ponpandian, N. Self-assembly of nanostructured hydroxyapatite spheres for photodegradation of methylene blue dye. Mater. Today Proc. 2019, 18, 1729-1734. [CrossRef]

55. Miranda, M.O.; Viana, B.C.; Honório, L.M.; Trigueiro, P.; Fonseca, M.G.; Franco, F.; Osajima, J.A.; Silva-Filho, E.C. Oxide-Clay Mineral as Photoactive Material for Dye Discoloration. Minerals 2020, 10, 132. [CrossRef]

56. Chen, D.; Cheng, Y.; Zhou, N.; Chen, P.; Wang, Y.; Li, K.; Huo, S.; Cheng, P.; Peng, P.; Zhang, R.; et al. Photocatalytic degradation of organic pollutants using $\mathrm{TiO}_{2}$-based photocatalysts: A review. J. Clean. Prod. 2020, 268, 121725. [CrossRef]

57. Reddy, M.P.; Venugopal, A.; Subrahmanyam, M. Hydroxyapatite photocatalytic degradation of calmagite (an azo dye) in aqueous suspension. Appl. Catal. B Environ. 2007, 69, 164-170. [CrossRef] 